\title{
FOXP1 abnormalities in lymphoma: translocation breakpoint mapping reveals insights into deregulated transcriptional control
}

\author{
Alison Goatly ${ }^{1}$, Chris M Bacon ${ }^{1}$, Shotaro Nakamura ${ }^{2}$, Hongtao Ye ${ }^{1}$, Insun Kim ${ }^{3}$, \\ Philip J Brown ${ }^{4}$, Agnès Ruskoné-Fourmestraux ${ }^{5}$, Pascale Cervera ${ }^{6}$, Berthold Streubel ${ }^{7}$, \\ Alison $\mathrm{H}_{\text {Banham }}^{4}$ and Ming-Qing $\mathrm{Du}^{1}$
}

${ }^{1}$ Department of Pathology, Division of Molecular Histopathology, University of Cambridge, Cambridge, UK; ${ }^{2}$ Department of Medicine and Clinical Science, Graduate School of Medical Sciences, Kyushu University, Fukuoka, Japan; ${ }^{3}$ Department of Pathology, Korea University Medical College, Seoul, Korea; ${ }^{4}$ Nuffield Department of Clinical Laboratory Sciences, University of Oxford, Oxford, UK; ${ }^{5} G E L D$, Department of Gastroenterology, AP-HP, Hôpital Saint Antoine, Paris, France; ${ }^{6}$ GELD, Department of Pathology, AP-HP, Hôpital Saint Antoine, Paris, France and ${ }^{7}$ Department of Pathology, Medical University of Vienna,

Vienna, Austria

\begin{abstract}
Deregulation of FOXP1 expression plays an important role in lymphoma development although the underlying molecular mechanism is poorly understood. FOXP1 is targeted by chromosome translocations in MALT lymphoma and diffuse large B-cell lymphoma, where high-level protein expression is associated with poor prognosis. Nonetheless, the incidence and nature of FOXP1 abnormalities at both the genetic and protein levels, and their correlation in these lymphomas are not well established. We investigated FOXP1 translocation, copy number change and protein expression in MALT Iymphoma $(n=321)$, MALT lymphoma with a diffuse large B-cell lymphoma component (59), nodal diffuse large B-cell lymphoma (64) and extranodal diffuse large B-cell lymphoma (151) by interphase fluorescence in situ hybridization and immunohistochemistry. FOXP1 translocation was found in eight MALT lymphomas and three MALT lymphomas with diffuse large B-cell lymphoma, with all positive cases originating in the stomach. In diffuse large B-cell lymphoma, the translocation was seen in 5 cases originating in the stomach (2), tonsil (1), large intestine (1) and lymph node (1). Immunoglobulin heavy chain gene was the translocation partner in 11 of the 16 positive cases. Fluorescence in situ hybridization mapping revealed FOXP1 breakpoints within the $5^{\prime}$ untranslated region of the gene (upstream of exon 6, the first coding exon of full-length FOXP1) in 14 cases, but downstream of exon 6 (most likely upstream of exon 8 ) in the remaining 2 cases. Three copies of the FOXP1 gene were observed in MALT Iymphoma (17\%), MALT Iymphoma with diffuse large B-cell lymphoma (12\%) and diffuse large B-cell lymphoma (32\%), including cases with FOXP1 translocation (19\%). Immunohistochemistry showed strong/ moderate FOXP1 staining in all the cases with FOXP1 translocation. However, FOXP1 expression was independent of FOXP1 translocation or copy number changes. Our findings suggest that (1) FOXP1 translocation may disrupt the full-length FOXP1 transcript and lead to expression of FOXP1 transcript variants with alternate $5^{\prime}$ ends and (2) mechanisms other than translocation and copy number changes are also responsible for FOXP1 overexpression in lymphoma.
\end{abstract}

Modern Pathology (2008) 21, 902-911; doi:10.1038/modpathol.2008.74; published online 16 May 2008

Keywords: FOXP1; chromosome translocation; FOXP1 expression; lymphoma

Correspondence: Professor M-Q Du, MB, PhD, FRCPath, Division of Molecular Histopathology, Department of Pathology, University of Cambridge, Box 231, Level 3 Lab Block, Addenbrooke's Hospital, Hills Road, Cambridge CB2 2QQ, UK.

E-mail: mqd20@cam.ac.uk

Received 03 January 2008; revised and accepted 24 January 2008; published online 16 May 2008
FOXP1 is a member of the forkhead box family of transcription factors that have diverse functions in different cell and tissue types. FOXP1 regulates Rag1 and Rag2 expression and is essential for B-cell development. $^{1}$ Apart from this, the function of FOXP1 is largely unknown. Nonetheless, FOXP1 function is unlikely to be confined to its role in 
B-cell development. Gene expression profiling studies show high expression of FOXP1 mRNA in activated B cells and activated B-cell-like diffuse large B-cell lymphomas. ${ }^{2}$ FOXP1 protein expression was seen in $40-60 \%$ of diffuse large B-cell lymphomas $^{3,4}$ and strong expression was significantly associated with inferior overall survival. ${ }^{4,5}$ Similarly, FOXP1 expression was found in 29\% of extranodal marginal zone B-cell lymphoma of mucosa-associated lymphoid tissue (MALT) and strong expression was associated with poor disease-free survival and transformation to diffuse large B-cell lymphoma. ${ }^{6}$ These findings suggest a role for FOXP1 expression in lymphoma pathogenesis.

In support of the above notion, FOXP1 genetic abnormalities were also described in lymphoma. Streubel et $\mathrm{al}^{7}$ first showed that FOXP1 was involved in $\mathrm{t}(3 ; 14)(\mathrm{p} 13 ; \mathrm{q} 32)$ in MALT lymphoma. FOXP1 translocation was present in $10 \%$ of MALT lymphomas, in those from the ocular adnexa $(4 / 20=20 \%)$, thyroid $(3 / 6=50 \%)$ and skin $(2 / 20=10 \%)$, but not in those from the salivary gland, stomach and lung. ${ }^{7}$ The translocation was subsequently found in one case of MALT lymphoma of the stomach, ${ }^{8}$ seven cases of diffuse large B-cell lymphoma of the stomach, thyroid and lymph nodes and also in two cases of B-cell non-Hodgkin lymphoma unclassified. ${ }^{8-10}$ In addition, FOXP1 gene amplification was reported in one case of diffuse large B-cell lymphoma in one study, ${ }^{8}$ but not in others, ${ }^{7,9-11}$ The discrepancies in the incidence of FOXP1 genetic abnormalities remain to be further investigated in a large series.

Of the 19 cases of FOXP1 translocation-positive lymphoma reported, ${ }^{7-10}$ FOXP1 breakpoints were characterized in 1 gastric MALT lymphoma and 1 gastric diffuse large B-cell lymphoma, both with $\mathrm{t}(3 ; 14) / F O X P 1-I G H$. In the gastric MALT lymphoma, the FOXP1 breakpoint was $38 \mathrm{~kb}$ upstream of the first noncoding exon 1 and the remaining FOXP1 sequence was joined to immunoglobulin heavy chain gene $(I G H)$ joining segment $6 .^{7}$ Thus, FOXP1 is overexpressed most likely as a result of strong transcriptional activity of the $I G H$ enhancer. In contrast, in the gastric diffuse large B-cell lymphoma, the FOXP1 breakpoint was in intron 2 (according to the Ensemble Genome Database), thus causing separation from its normal promoter. The remaining FOXP1 sequence was joined to $I G H-C \alpha 1$ but in an opposite transcriptional orientation. ${ }^{9}$ Despite this, FOXP1 protein was strongly expressed, suggesting expression of variant FOXP1 transcripts under the control of an alternative promoter. ${ }^{9}$ Although little is known about the transcriptional regulation of FOXP1, the different FOXP1 breakpoints described are expected to have significantly different effects on FOXP1 transcriptional control. However, the number of FOXP1 translocation cases investigated for FOXP1 breakpoints is small and characterization of breakpoints in further cases is needed to understand how the translocation impacts on FOXP1 transcriptional regulation. Such knowledge is critical not only for understanding the role of FOXP1 translocation in lymphoma pathogenesis, but also for studies of FOXP1 transcriptional regulation in normal and malignant $\mathrm{B}$ cells lacking FOXP1 genetic abnormalities. We have screened a large series of MALT lymphomas of various sites, and diffuse large B-cell lymphomas from nodal and extranodal sites for FOXP1 translocation and mapped the FOXP1 breakpoints in the 16 translocation-positive cases identified.

\section{Materials and methods}

\section{Materials}

A total of 595 cases of lymphoma were studied and their histological diagnoses were reviewed. These included 321 cases of MALT lymphoma, 59 cases of MALT lymphoma with a diffuse large B-cell lymphoma and 215 cases of diffuse large B-cell lymphoma; and their tissue origins are summarized in Table 1. Formalin-fixed paraffin-embedded tissues were retrieved from each case. The use of

Table 1 Incidences of FOXP1 translocation and numerical changes in lymphoma

\begin{tabular}{|c|c|c|c|c|c|c|}
\hline \multirow{2}{*}{$\begin{array}{l}\text { Lymphoma type } \\
\text { MALT lymphoma }\end{array}$} & \multirow{2}{*}{$\begin{array}{l}\text { Primary site } \\
\text { Gastric }\end{array}$} & \multirow{2}{*}{$\begin{array}{c}\text { No. of cases } \\
188\end{array}$} & \multicolumn{2}{|c|}{$\begin{array}{c}\text { No. of cases with FOXP1 } \\
\text { translocation }\end{array}$} & \multicolumn{2}{|c|}{$\begin{array}{l}\text { No. of cases with } 3 \\
\text { copies of FOXP1 }\end{array}$} \\
\hline & & & 8 & $4 \%$ & 34 & $18 \%$ \\
\hline & Non-gastric ${ }^{a}$ & 133 & 0 & $0 \%$ & 22 & $17 \%$ \\
\hline MALT lymphoma+diffuse large & Gastric & 53 & 3 & $6 \%$ & 4 & $8 \%$ \\
\hline B-cell lymphoma & Non-gastric ${ }^{b}$ & 6 & 0 & $0 \%$ & 3 & $50 \%$ \\
\hline \multirow[t]{3}{*}{ Diffuse large B-cell lymphoma } & Nodal & 64 & 1 & $2 \%$ & 28 & $44 \%$ \\
\hline & Extra nodal gastric & 69 & 2 & $3 \%$ & 16 & $23 \%$ \\
\hline & Extra nodal non-gastric ${ }^{\mathrm{c}}$ & 82 & 2 & $2 \%$ & 27 & $33 \%$ \\
\hline
\end{tabular}

\footnotetext{
${ }^{a}$ MALT lymphomas from the salivary gland (40), ocular adnexa (46), lung (13), intestines (10), thyroid (7), abdominal wall, breast, bladder, tonsil, testes, liver, thymus, larynx and pharynx.

${ }^{b}$ MALT lymphoma with a diffuse large B-cell lymphoma component from the thyroid (4) and intestines (2).

${ }^{\mathrm{c}}$ Diffuse large B-cell lymphoma from the thyroid (19), tonsils (13), intestines (21), salivary gland (3), skin, testes and nasopharynx. The two cases with FOXP1 translocation are from the tonsil (1/13), and intestines (1/21).
} 
Table 2 BAC clones used to generate interphase FISH assays for detection of FOXP1 translocation

\begin{tabular}{|c|c|c|c|c|c|}
\hline BAC Clone & Abbreviation & Gene & Position $(\mathrm{Mb})^{\mathrm{a}}$ & Label color & Probe set \\
\hline RP11-0118 O11 & O11 & FOXP1 & $70.63-70.79$ & Orange & BAP 1, fusion \\
\hline RP11-01031 N18 & N18 & FOXP1 & $70.72-70.91$ & Orange & BAP 1, fusion \\
\hline RP11-0430 J3 & J3 & FOXP1 & $70.86-71.02$ & Orange & BAP 1 , fusion \\
\hline RP11-0079 P21 & P21 & FOXP1 & $71.02-71.19$ & Orange & BAP 3 \\
\hline RP11-0090 H15 & H15 & FOXP1 & $71.17-71.30$ & Orange & BAP 3 \\
\hline RP11-0298 C2 & $\mathrm{C} 2$ & FOXP1 & $71.26-71.42$ & Orange & BAP 2,3 \\
\hline CTD-2011 M13 & M13 & FOXP1 & $71.51-71.66$ & Orange & BAP 2 \\
\hline RP11-0154 H23 & $\mathrm{H} 23$ & FOXP1 & $71.62-71.82$ & Green & BAP 1,3 \\
\hline RP11-0266 O22 & $\mathrm{O} 22$ & FOXP1 & $71.73-71.89$ & Green & BAP $1,2,3$ \\
\hline RP11-0321 A23 & A23 & FOXP1 & $71.87-72.05$ & Green & BAP $1,2,3$ \\
\hline RP11-150 I16 & I16 & IGH & $104.38-104.53$ & Green & Fusion \\
\hline RP11-817 G24 & G24 & $I G H$ & $104.53-104.76$ & Green & Fusion \\
\hline RP11-937 M13 & 937 M13 & $I G H$ & $104.76-104.95$ & Green & Fusion \\
\hline
\end{tabular}

BAP: break-apart probe.

${ }^{\text {a }}$ Positions of BACs are according to Ensembl and the UCSC Genome Browser.

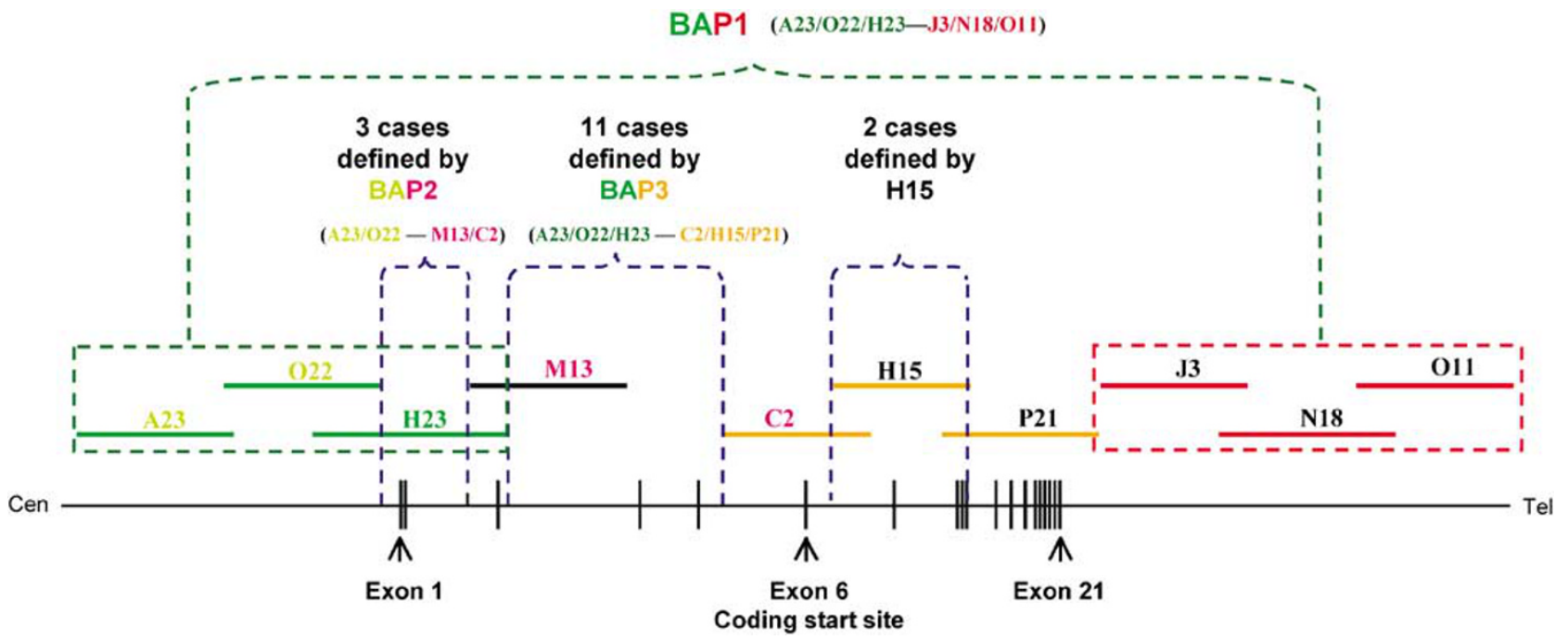

Figure 1 Schematic representation of FOXP1 genomic structure and the BAC clones used for detection of FOXP1 translocation and mapping of FOXP1 breakpoints. Please refer to Table 2 for the full name and position of the BAC clones.

such archival tissues for research was approved by the local ethics committees of the authors' institutions, where required.

\section{Fluorescence In Situ Hybridization}

A series of 10 BAC clones mapping to various positions of the FOXP1 gene were used to form three break-apart (BAP) fluorescence in situ hybridization (FISH) assays to detect FOXP1 translocation and to map FOXP1 breakpoints (Table 2; Figure 1). The 3 BAC clones telomeric of the FOXP1 gene were combined with 3 BAC clones centromeric of the $I G H$ locus (kindly provided by Professor Reiner Siebert) to form a FISH assay to detect FOXP1-IGH fusion. BAC DNA extraction and labeling were performed essentially as previously described. ${ }^{12}$ The specificity and efficacy of the probes were tested on metaphase slides and on formalin-fixed paraffin-embedded tissue sections of a MALT lymphoma with $\mathrm{t}(3 ; 14)(\mathrm{p} 13 ; \mathrm{q} 32) / F O X P 1-I G H$.

Interphase FISH was performed as described previously. ${ }^{12}$ For each probe set, the mean plus three standard deviations of false positive signals in 100 nuclei from seven reactive tonsils was used as the cut-off value for the diagnosis of chromosomal aberrations. ${ }^{12}$ FOXP1 translocation-positive cases were further screened with IGH (Vysis/Abbott Laboratories Ltd, UK), $I G-\kappa$ and $I G-\lambda$ BAP probes (kindly provided by Professor Reiner Siebert) to identify potential translocation partners. All MALT lymphomas with FOXP1 translocation were investigated with a MALT1 BAP probe, whereas diffuse large B-cell lymphomas with FOXP1 translocation were investigated with $B C L 6, B C L 2$ and $c-M Y C$ BAP probes (Vysis/Abbott Laboratories Ltd). 


\section{Immunohistochemistry}

FOXP1 immunohistochemistry was performed on formalin-fixed paraffin-embedded tissue sections using the JC12 mouse monoclonal antibody, which recognizes specifically an epitope in the C-terminus (within exons 18-21) of FOXP1. Various conditions including different antibody dilutions and antigen retrieval methods were tested and the optimized conditions are described below. Briefly, sections were pretreated in a microwave for $15 \mathrm{~min}$ in DAKO Low Target Retrieval Solution and then incubated with the JC12 antibody (1/150 dilution) for $45 \mathrm{~min}$, followed by incubation with secondary antibody and visualization by the streptavidin-immunoperoxidase method. FOXP1 immunostaining was evaluated independently by three assessors (AG, CMB, MQD) and scored according to the percentage of positivity $(<30 \%, 30-70 \%,>70 \%$ cells $)$ and the intensity of immunostaining (weak, moderate, strong) as described previously.,6

CD10, Bcl-6 and MUM1 were similarly immunostained in diffuse large B-cell lymphomas with FOXP1 translocation and the staining was assessed semiquantitatively by visual estimation. Cases were considered positive if $30 \%$ or more of the tumor cells were stained. Diffuse large B-cell lymphomas were subclassified into the germinal center B-celllike or non-germinal center B-cell-like subtypes as described previously. ${ }^{3}$

\section{Statistical Analysis}

The $\chi^{2}$-test was used to analyze the difference in FOXP1 staining between MALT lymphoma and diffuse large B-cell lymphoma.

\section{Results}

\section{FOXP1 Genetic Aberrations in Lymphoma}

In total, 16 of the 595 cases of lymphoma studied with FOXP1 BAP probe 1 showed evidence of a FOXP1 translocation. These included eight MALT lymphomas, three MALT lymphomas with a diffuse large B-cell lymphoma component and five diffuse large B-cell lymphomas (Table 1). In the three cases of MALT lymphoma with a diffuse large B-cell lymphoma component, FOXP1 translocation was detected in the MALT lymphoma but presence of the translocation in the diffuse large B-cell lymphoma component could not be investigated due to the absence of diffuse large B-cell lymphoma in the tissues available for research. All cases of MALT lymphoma and MALT lymphoma with a diffuse large B-cell lymphoma component harboring FOXP1 translocation were from the stomach, accounting for 4 and $6 \%$ of the corresponding lymphoma subtype of the stomach, respectively. The five translocationpositive diffuse large B-cell lymphomas were from the stomach ( $n=2,3 \%)$, intestine $(n=1,5 \%)$, tonsil $(n=1,8 \%)$ and lymph node $(n=1,2 \%)$.

Gain of one or more extra copies of the FOXP1 gene was seen in $17 \%$ of MALT lymphomas, $12 \%$ of MALT lymphomas with a diffuse large B-cell lymphoma component and $33 \%$ of diffuse large B-cell lymphomas (Table 1). These included three cases (one thyroid MALT lymphoma with diffuse large B-cell lymphoma, one intestinal diffuse large B-cell lymphoma and one gastric diffuse large B-cell lymphoma) showing four or more extra copies of the FOXP1 gene. Gain of an extra copy of the FOXP1 gene, but not the translocated allele, was seen in 3 of the 16 FOXP1 translocation-positive cases (19\%).

Further interphase FISH with MALT1 BAP probe showed that none of the FOXP1 translocation positive MALT lymphomas or MALT lymphomas with diffuse large B-cell lymphoma had a translocation involving the MALT1 locus. For diffuse large B-cell lymphoma with FOXP1 translocation, interphase FISH was performed with BCL2, $C-M Y C$ and BCL6 BAP probes, respectively, and only one case (no. 14) was found to harbor a BCL6 translocation.

\section{Clinicopathological Features of Lymphomas with FOXP1 Translocation}

There were neither apparently uniform clinical nor histological features associated with these FOXP1 translocation-positive cases (Table 3). All MALT lymphoma cases showed characteristic histology and immunophenotype. Follicular colonization and prominent plasma-cell differentiation were each seen in three cases, with one case displaying both histological features. One case of stage-I gastric MALT lymphoma (no. 2) was treated by Helicobacter pylori eradication but showed no response to this first-line treatment. ${ }^{14,15}$ Interestingly, one case of stage-I MALT lymphoma with a diffuse large B-cell lymphoma component (no. 9) showed complete remission following $H$. pylori eradication. With the exception of one patient with gastric MALT lymphoma who died of postsurgical infection, all other cases of MALT lymphoma with or without diffuse large Bcell lymphoma showed favorable responses to treatment.

Of the five cases of diffuse large B-cell lymphoma, two cases were of germinal center B-cell-like subtype and the remaining three were of non-germinal center B-cell-like subtype. ${ }^{3}$ The histological and clinical features of these cases are summarized in Table 3.

\section{Identification of the Translocation Partner of FOXP1}

Interphase FISH with an IGH BAP probe showed a break in the IGH locus in 11 of the 16 FOXP1 translocation-positive cases (Table 3). Further FISH with the FOXP1-IGH fusion probe confirmed $I G H$ as the translocation partner in each of these 11 cases. Of the remaining five cases in which FOXP1 
Table 3 Summary of cases with FOXP1 translocation

\begin{tabular}{|c|c|c|c|c|c|c|c|c|c|c|}
\hline $\begin{array}{l}\text { Case } \\
\text { no. }\end{array}$ & Site & Age/sex & $\begin{array}{l}\text { Histological } \\
\text { diagnosis }\end{array}$ & $\begin{array}{l}\text { Histological } \\
\text { features }\end{array}$ & $\begin{array}{l}\text { CD10/BCL6/ } \\
\text { MUM1 }\end{array}$ & $\begin{array}{l}\text { Clinical } \\
\text { stage }^{1}\end{array}$ & $\begin{array}{l}\text { Treatment } \\
\text { and follow-up }\end{array}$ & $\begin{array}{l}\text { FOXP1 and } \\
\text { other genetic } \\
\text { abnormality }\end{array}$ & $\begin{array}{l}\text { FOXP1 } \\
\text { breakpoint }\end{array}$ & $\begin{array}{l}\text { FOXP1 immunohisto- } \\
\text { chemistry }\end{array}$ \\
\hline 1 & Stomach & $31 / \mathrm{F}$ & MALT lymphoma & $\begin{array}{l}\text { Centrocyte-like cells, } \\
\text { lymphoepithelial lesions }\end{array}$ & & $\mathrm{n} / \mathrm{a}$ & $\mathrm{n} / \mathrm{a}$ & $\begin{array}{l}\text { FOXP1-IGH, an } \\
\text { extra copy of } \\
\text { FOXP1 }\end{array}$ & $\begin{array}{l}18 \mathrm{~kb} \text { upstream of } \\
\text { exon } 1 \text { to } 54 \mathrm{~kb} \\
\text { downstream } \\
\text { of exon } 2\end{array}$ & $\begin{array}{l}75 \% \text {, strong staining } \\
\text { in most positive cells, } \\
\text { including those in } \\
\text { lymphoepithelial } \\
\text { lesions }\end{array}$ \\
\hline 2 & Stomach & $47 / \mathrm{F}$ & MALT lymphoma & $\begin{array}{l}\text { Small and medium-sized } \\
\text { centrocyte-like cells, } \\
\text { lymphoepithelial lesions }\end{array}$ & & I & $\begin{array}{l}\text { Failed to respond } H \text {. } \\
\text { pylori eradication, total } \\
\text { gastrectomy, CR } \\
\text { for } 48 \text { months, } \\
\text { alive }\end{array}$ & FOXP1-IGH & $\begin{array}{l}18 \mathrm{~kb} \text { upstream of } \\
\text { exon } 1 \text { to } 54 \mathrm{~kb} \\
\text { downstream } \\
\text { of exon } 2\end{array}$ & $\mathrm{n} / \mathrm{a}$ \\
\hline 3 & Stomach & $62 / \mathrm{M}$ & MALT lymphoma & $\begin{array}{l}\text { Atypical medium-sized } \\
\text { lymphoid cells, } \\
\text { lymphoepithelial lesions, } \\
\text { follicular colonisation }\end{array}$ & & I & $\begin{array}{l}\text { Subtotal gastrectomy, } \\
130 \text { months, alive }\end{array}$ & FOXP1-IGH & $\begin{array}{l}\text { Intron } 3 \text { to } 13 \mathrm{~kb} \\
\text { downstream } \\
\text { of exon } 5\end{array}$ & $\begin{array}{l}80 \% \text {, strong staining } \\
\text { in majority of positive } \\
\text { cells }\end{array}$ \\
\hline 4 & Stomach & $16 / \mathrm{F}$ & MALT lymphoma & $\begin{array}{l}\text { Centrocyte-like cells, } \\
\text { monocytoid cells, } \\
\text { lymphoepithelial lesions, } \\
\text { follicular colonisation }\end{array}$ & & I & $\begin{array}{l}\text { Subtotal gastrectomy, } \\
117 \text { months, alive }\end{array}$ & FOXP1-IGH & $\begin{array}{l}\text { Intron } 3 \text { to } 13 \mathrm{~kb} \\
\text { downstream } \\
\text { of exon } 5\end{array}$ & $\begin{array}{l}80 \% \text {, strong staining } \\
\text { in most positive cells }\end{array}$ \\
\hline 5 & Stomach & $16 / \mathrm{M}$ & MALT lymphoma & $\begin{array}{l}\text { Centrocyte-like cells, } \\
\text { lymphoepithelial lesions, } \\
\text { prominent plasma cell } \\
\text { differentiation }\end{array}$ & & II-1 & $\begin{array}{l}\text { Subtotal gastrectomy, } \\
240 \text { months, died of } \\
\text { accident without } \\
\text { evidence of lymphoma }\end{array}$ & $\begin{array}{l}\text { FOXP1 } \\
\text { translocation } \\
\text { with unknown } \\
\text { partner }\end{array}$ & $\begin{array}{l}\text { Intron } 3-13 \mathrm{~kb} \\
\text { downstream } \\
\text { of exon } 5\end{array}$ & $\mathrm{n} / \mathrm{a}$ \\
\hline 6 & Stomach & $64 / \mathrm{M}$ & MALT lymphoma & $\begin{array}{l}\text { Centrocyte-like cells, } \\
\text { lymphoepithelial lesions, } \\
\text { prominent plasma cell } \\
\text { differentiation, follicular } \\
\text { colonisation }\end{array}$ & & II-1 & $\begin{array}{l}\text { Subtotal gastrectomy, } \\
\text { lost in follow-up }\end{array}$ & FOXP1-IGH & $\begin{array}{l}\text { Intron } 3 \text { to } 13 \mathrm{~kb} \\
\text { downstream of } \\
\text { exon } 5\end{array}$ & $\begin{array}{l}90 \% \text {, strong staining } \\
\text { in most positive cells, } \\
\text { including those in } \\
\text { IELs }\end{array}$ \\
\hline 7 & Stomach & $64 / \mathrm{M}$ & MALT lymphoma & $\begin{array}{l}\text { Centrocyte-like cells, } \\
\text { lymphoepithelial lesions, } \\
\text { prominent plasma cell } \\
\text { differentiation, pleomorphic } \\
\text { monocytoid cells }\end{array}$ & & II-2 & $\begin{array}{l}\text { Total gastrectomy, } \\
2 \text { months, died of } \\
\text { postoperative infection }\end{array}$ & $\begin{array}{l}\text { FOXP1 } \\
\text { translocation } \\
\text { with unknown } \\
\text { partner, but not with } \\
I G H \text { and } \\
\text { IGк loci, an extra copy } \\
\text { of FOXP1 } \\
\text { and MALT1 }\end{array}$ & $\begin{array}{l}\text { Intron } 3 \text { to } 13 \mathrm{~kb} \\
\text { downstream } \\
\text { of exon } 5\end{array}$ & $\begin{array}{l}50 \%, \text { moderate } \\
\text { staining in most } \\
\text { positive cells }\end{array}$ \\
\hline 8 & Stomach & $48 / \mathrm{F}$ & MALT lymphoma & Centrocyte-like cells & & I & $\begin{array}{l}6 \text { cycles chemotherapy } \\
\text { (CEOP-B), CR, } \\
\text { but lost in } \\
\text { follow-up }\end{array}$ & FOXP1-IGH & $\begin{array}{l}\text { Intron } 3 \text { to } 13 \mathrm{~kb} \\
\text { downstream } \\
\text { of exon } 5\end{array}$ & $\mathrm{n} / \mathrm{a}$ \\
\hline 9 & Stomach & $50 / \mathrm{M}$ & $\begin{array}{l}\text { MALT } \\
\text { lymphoma+diffuse } \\
\text { large B-cell } \\
\text { lymphoma }\end{array}$ & $\begin{array}{l}\text { Small lymphocytes, } \\
\text { aggregates of large lymphoid } \\
\text { cells }\end{array}$ & & I & $\begin{array}{l}\text { H. pylori } \\
\text { eradication, CR, } \\
44 \text { months, alive }\end{array}$ & $\begin{array}{l}\text { FOXP1-IGH an } \\
\text { extra copy of } \\
\text { MALT1 }\end{array}$ & $\begin{array}{l}\text { Intron } 3 \text { to } 13 \mathrm{~kb} \\
\text { downstream } \\
\text { of exon } 5\end{array}$ & $\begin{array}{l}\text { Assessed in MALT } \\
\text { lymphoma, } 60 \% \text {, } \\
\text { strong staining in } \\
\text { majority of positive } \\
\text { cells }\end{array}$ \\
\hline 10 & Stomach & $50 / \mathrm{F}$ & $\begin{array}{l}\text { MALT } \\
\text { lymphoma+diffuse } \\
\text { large B-cell } \\
\text { lymphoma }\end{array}$ & $\begin{array}{l}\text { Centrocyte-like cells, foci of } \\
\text { diffuse large B-cell } \\
\text { lymphoma }\end{array}$ & & $\mathrm{n} / \mathrm{a}$ & $\mathrm{n} / \mathrm{a}$ & FOXP1-IGH & $\begin{array}{l}60 \mathrm{~kb} \text { upstream of } \\
\text { exon } 7 \text { to exon } 10\end{array}$ & $\begin{array}{l}\text { Assessed in MALT } \\
\text { lymphoma, } 85 \% \text {, } \\
\text { strong staining in } \\
\text { most positive cells }\end{array}$ \\
\hline 11 & Stomach & $70 / \mathrm{M}$ & $\begin{array}{l}\text { MALT } \\
\text { lymphoma+diffuse } \\
\text { large B-cell } \\
\text { lymphoma }\end{array}$ & $\begin{array}{l}\text { Centrocyte-like cells, areas } \\
\text { with numerous large cells, } \\
\text { foci of diffuse large B-cell } \\
\text { lymphoma }\end{array}$ & & I & $\begin{array}{l}\text { Subtotal } \\
\text { gastrectomy+multiagent } \\
\text { chemotherapy, CR, } 48 \\
\text { months, alive }\end{array}$ & $\begin{array}{l}\text { FOXP1 translocation } \\
\text { with unknown } \\
\text { partner, but not with } \\
I G H, I G \kappa \text { and } I G \lambda\end{array}$ & $\begin{array}{l}60 \mathrm{~kb} \text { upstream of } \\
\text { exon } 7 \text { to } \\
\text { exon } 10\end{array}$ & $\begin{array}{l}\text { Assessed in MALT } \\
\text { lymphoma, } 85 \% \text {, } \\
\text { moderate to strong } \\
\text { staining in most } \\
\text { positive cells }\end{array}$ \\
\hline
\end{tabular}


Table 3 Continued

\begin{tabular}{|c|c|c|c|c|c|c|c|c|c|c|}
\hline $\begin{array}{l}\text { Case } \\
\text { no. }\end{array}$ & Site & Age/sex & $\begin{array}{l}\text { Histological } \\
\text { diagnosis }\end{array}$ & $\begin{array}{l}\text { Histological } \\
\text { features }\end{array}$ & $\begin{array}{l}\text { CD10/BCL6/ } \\
\text { MUM1 }\end{array}$ & $\begin{array}{l}\text { Clinical }_{\text {stage }^{1}} \\
\end{array}$ & $\begin{array}{l}\text { Treatment } \\
\text { and follow-up }\end{array}$ & $\begin{array}{l}\text { FOXP1 and } \\
\text { other genetic } \\
\text { abnormality }\end{array}$ & $\begin{array}{l}\text { FOXP1 } \\
\text { breakpoint }\end{array}$ & $\begin{array}{l}\text { FOXP1 immunohisto- } \\
\text { chemistry }\end{array}$ \\
\hline 12 & Stomach & $48 / \mathrm{F}$ & $\begin{array}{l}\text { Diffuse large B-cell } \\
\text { lymphoma }\end{array}$ & $\begin{array}{l}\text { Medium-sized and large } \\
\text { pleomorphic cells }\end{array}$ & $\begin{array}{l}\text { Germinal } \\
\text { center B-cell- } \\
\text { like (CD10+, } \\
\text { BCL6+, } \\
\text { MUM1-) }\end{array}$ & II-1 & $\begin{array}{l}\text { Subtotal } \\
\text { gastrectomy+multiagent } \\
\text { chemotherapy, CR, } 84 \\
\text { months, alive }\end{array}$ & $\begin{array}{l}\text { FOXP1-IGH an extra } \\
\text { copy of MALT1 }\end{array}$ & $\begin{array}{l}\text { Intron } 3 \text { to } 13 \mathrm{~kb} \\
\text { downstream } \\
\text { of exon } 5\end{array}$ & $\begin{array}{l}75 \% \text {, moderate } \\
\text { staining in most of } \\
\text { positive cells }\end{array}$ \\
\hline 13 & Stomach & $28 / \mathrm{F}$ & $\begin{array}{l}\text { Diffuse large B-cell } \\
\text { lymphoma }\end{array}$ & Large atypical cells & $\begin{array}{l}\text { Germinal } \\
\text { center B-cell- } \\
\text { like (CD10-, } \\
\text { Bcl6+, MUM1-) }\end{array}$ & II-2 & $\begin{array}{l}\text { Subtotal gastrectomy, } \\
6 \text { cycles of CEOP-B, } \\
\text { then } 4 \text { cycles of ESHAP, } \\
1 \text { cycle IVAM, died } 11 \\
\text { months after diagnosis }\end{array}$ & $\begin{array}{l}\text { FOXP1 translocation } \\
\text { with unknown } \\
\text { partner, but not with } \\
I G H, I G \kappa \text { and } I G \lambda \text {, an } \\
\text { extra copy of } F O X P 1 \\
\text { and } B C L 6\end{array}$ & $\begin{array}{l}\text { Intron } 3 \text { to } 13 \mathrm{~kb} \\
\text { downstream of } \\
\text { exon } 5\end{array}$ & $\begin{array}{l}70 \% \text {, moderate to } \\
\text { strong staining in } \\
\text { most positive cells }\end{array}$ \\
\hline 14 & $\begin{array}{l}\text { Large } \\
\text { intestine }\end{array}$ & $58 / \mathrm{M}$ & $\begin{array}{l}\text { Diffuse large B-cell } \\
\text { lymphoma }\end{array}$ & $\begin{array}{l}\text { Large centroblastic and } \\
\text { pleomorphic cells }\end{array}$ & $\begin{array}{l}\text { Non-germinal } \\
\text { center B-cell- } \\
\text { like (CD10-, } \\
\text { Bcl6+, MUM1+) }\end{array}$ & I & $\begin{array}{l}\text { Right-colectomy, then } 6 \\
\text { cycle CEOP-B } \\
\text { chemotherapy, } \\
28 \text { months later, } \\
\text { lymphoma relapse in } \\
\text { nasopharynx, cervical } \\
\text { and inguinal lymph } \\
\text { nodes, treated with } \\
\text { ESHAP but lymphoma } \\
\text { relasped in nasal cavity, } \\
\text { further treated with IVAM } \\
\text { and R-COP, CR for } 38 \\
\text { months in the last } \\
\text { follow-up }\end{array}$ & $\begin{array}{l}\text { FOXP1-IGH } B C L 6 \\
\text { translocation }\end{array}$ & $\begin{array}{l}\text { Intron } 3 \text { to } 13 \mathrm{~kb} \\
\text { downstream } \\
\text { of exon } 5\end{array}$ & $\begin{array}{l}75 \% \text {, strong staining } \\
\text { in majority of } \\
\text { positive cells }\end{array}$ \\
\hline 15 & Tonsil & $43 / \mathrm{M}$ & $\begin{array}{l}\text { Diffuse large B-cell } \\
\text { lymphoma }\end{array}$ & $\begin{array}{l}\text { Medium-sized } \\
\text { atypical cells }\end{array}$ & $\begin{array}{l}\text { Non-germinal } \\
\text { center B-cell- } \\
\text { like (CD10-, } \\
\text { Bcl6-, MUM1+) }\end{array}$ & I & $\mathrm{n} / \mathrm{a}$ & $\begin{array}{l}\text { FOXP1 translocation } \\
\text { with unknown } \\
\text { partner, but not with } \\
I G H, I G \kappa \text { and } I G \lambda \text { an } \\
\text { extra copy of BCL6 }\end{array}$ & $\begin{array}{l}\text { Intron } 3 \text { to } 13 \mathrm{~kb} \\
\text { downstream } \\
\text { of exon } 5\end{array}$ & $\begin{array}{l}95 \% \text {, strong staining } \\
\text { in most positive cells }\end{array}$ \\
\hline 16 & $\begin{array}{l}\text { Lymph } \\
\text { node }\end{array}$ & $47 / \mathrm{M}$ & $\begin{array}{l}\text { Diffuse large B-cell } \\
\text { lymphoma (cervical } \\
\text { lymph nodes) } \\
\text { relapsed as follicular } \\
\text { lymphoma grade } \\
\text { 3a+diffuse large } \\
\text { B-cell lymphoma } \\
\text { (axillary lymph } \\
\text { nodes) }\end{array}$ & $\begin{array}{l}\text { Diffuse large B-cell } \\
\text { lymphoma: centroblastic } \\
\text { and multilobated cells. } \\
\text { follicular lymphoma: } \\
\text { centrocytes and } \\
\text { centroblasts }\end{array}$ & $\begin{array}{l}\text { Non-germinal } \\
\text { center B-cell- } \\
\text { like (CD10-, } \\
\text { Bcl6+, MUM1+) }\end{array}$ & II & $\begin{array}{l}6 \text { cycle of CEOP-B, } \\
\text { relapse, then treated } \\
\text { with multiagent } \\
\text { chemotherapy, CR, but } \\
\text { lymphoma relapsed again } \\
\text { and died of disease at } 52 \\
\text { months follow-up }\end{array}$ & FOXP1-IGH & $\begin{array}{l}18 \mathrm{~kb} \text { upstream of } \\
\text { exon } 1 \text { to } 54 \mathrm{~kb} \\
\text { downstream } \\
\text { of exon-2 }\end{array}$ & $\begin{array}{l}50 \%, \text { moderate } \\
\text { staining in majority } \\
\text { of positive cells }\end{array}$ \\
\hline
\end{tabular}

CEOP-B: cyclophosphamide, epirubicin, vincristine, prednisolone and bleomycin; CR: complete remission; ESHAP: etoposide, methylprednisolone, high-dose cytarabine and cisplatin; IVAM:

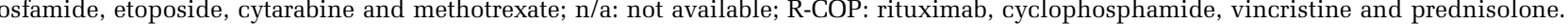

${ }^{a}$ According to Lugano International Conference classification for clinical staging of gastrointestinal lymphoma. ${ }^{13}$ 
Table 4 Correlation of FOXP1 expression and its genetic abnormalities in MALT lymphoma and diffuse large B-cell lymphoma

\begin{tabular}{|c|c|c|c|c|c|c|c|c|c|c|c|}
\hline \multirow{2}{*}{$\begin{array}{l}\text { FOXP1 genetic } \\
\text { changes }\end{array}$} & \multirow{2}{*}{$\begin{array}{l}\text { No. of } \\
\text { cases }\end{array}$} & \multirow{2}{*}{\multicolumn{2}{|c|}{$\begin{array}{l}\text { Negative or } \\
\text { FOXP1 expression in } \\
<30 \% \text { cells }\end{array}$}} & \multicolumn{4}{|c|}{ FOXP1 expression in $30-70 \%$ cells } & \multicolumn{4}{|c|}{ FOXP1 expression in $>70 \%$ cells } \\
\hline & & & & \multicolumn{2}{|c|}{ Weak staining } & \multicolumn{2}{|c|}{$\begin{array}{l}\text { Moderate or strong } \\
\text { staining }\end{array}$} & \multicolumn{2}{|c|}{ Weak staining } & \multicolumn{2}{|c|}{$\begin{array}{c}\text { Moderate or strong } \\
\text { staining }\end{array}$} \\
\hline \multicolumn{12}{|l|}{ MALT lymphoma } \\
\hline Translocation & 5 & 0 & $0 \%$ & 0 & $0 \%$ & 1 & $20 \%$ & 0 & $0 \%$ & 4 & $80 \%$ \\
\hline 3 copies & 19 & 8 & $42 \%$ & 4 & $21 \%$ & 3 & $16 \%$ & 0 & $0 \%$ & 4 & $21 \%$ \\
\hline Normal & 95 & 45 & $47 \%$ & 8 & $8 \%$ & 15 & $16 \%$ & 3 & $3 \%$ & 24 & $25 \%$ \\
\hline \multicolumn{12}{|c|}{ Diffuse large B-cell lymphoma } \\
\hline Translocation & 5 & 0 & $0 \%$ & 0 & $0 \%$ & 1 & $20 \%$ & 0 & $0 \%$ & 4 & $80 \%$ \\
\hline 3 copies & 32 & 9 & $28 \%$ & 3 & $9 \%$ & 5 & $16 \%$ & 0 & $0 \%$ & 15 & $47 \%$ \\
\hline Normal & 102 & 31 & $30 \%$ & 10 & $30 \%$ & 12 & $11 \%$ & 2 & $2 \%$ & 47 & $46 \%$ \\
\hline
\end{tabular}

translocation was not associated with $I G H$, further interphase FISH with IG- $\kappa k a p p a$ and $I G-\lambda$ BAP probes were performed in four cases where materials were available (Table 3 ), and the results were negative.

\section{Mapping FOXP1 Breakpoints}

To map the location of FOXP1 breakpoints, further interphase FISH was performed using FOXP1 BAP probes 2 and 3 , and additionally with BAC clones C2/H15/P21. Three cases (nos. 1, 2 and 16) showed a split signal with BAP probe 2, indicating breakpoints between BAC clones O22 and M13, corresponding to the region spanning $18 \mathrm{~kb}$ upstream of exon 1 to $54 \mathrm{~kb}$ downstream of exon 2 (Figure 1). Although the precise positions of the breakpoints in these cases were unknown, the relative sizes of the exons and introns in this region suggest that these breakpoints most likely reside downstream of exon 1. Eleven cases (nos. 3-9 and 12-15) displayed a split signal with BAP probe 3 , indicating breakpoints between $\mathrm{H} 23$ and $\mathrm{C} 2$, corresponding to the region spanning from intron 3 to $13 \mathrm{~kb}$ downstream of exon 5 (Figure 1). The remaining two cases (nos. 10 and 11) showed no evidence of split signals with BAP probes 2 and 3 , but displayed split signals with BAC clones C2/H15/ P21. Further interphase FISH localized the breakpoint to the region covered by H15, which spans $60 \mathrm{~kb}$ upstream of exon 7 to exon 10 (Figure 1). In view of the long introns 6-7 but short exons 8-10 and introns $8-9$, it is likely that the breakpoints in these two cases are located upstream of exon 8.

There was no difference in the location of FOXP1 breakpoints between MALT lymphoma and diffuse large B-cell lymphoma, or between cases with and without $I G H$ as the translocation partner.

\section{Correlation of FOXP1 Protein Expression with Its Gene Abnormalities}

FOXP1 protein expression was investigated by immunohistochemistry in 119 cases of MALT lymphoma, 3 cases of FOXP1 translocation positive MALT lymphomas with diffuse large B-cell lymphoma and 139 cases of diffuse large B-cell lymphoma, where tissues were available. Strong uniform FOXP1 staining was found in most FOXP1 translocation-positive cases of MALT lymphoma and diffuse large B-cell lymphoma (Tables 3 and 4; Figure 2). However, such strong homogenous FOXP1 staining was also frequently seen in FOXP1 translocation-negative lymphomas, irrespective of the presence of normal or increased copy number of the FOXP1 gene, being significantly more frequent in diffuse large B-cell lymphoma (46\%) than in MALT lymphomas (25\%; $P<0.0005$; Table 4).

\section{Discussion}

Unlike t(11;18)(q21;q21)/API2-MALT1, t(1;14)(p22;q32)/ BCL10-IGH and $\mathrm{t}(14 ; 18)(\mathrm{q} 32 ; \mathrm{q} 21) / I G H-M A L T 1$ which are specifically associated with MALT lymphoma, ${ }^{12,16,17}$ FOXP1 translocation has been found in MALT lymphoma and diffuse large B-cell lymphoma of nodal and extranodal sites. ${ }^{7-10}$ However, similar to these three translocations, FOXP1 translocation also occurs at variable frequencies in MALT lymphoma of different sites. Our results, based on screening a large series of MALT lymphomas of various sites, showed that FOXP1 translocation was associated with those of the stomach, but not other mucosal sites. In line with this, two of the five extranodal diffuse large B-cell lymphomas with FOXP1 translocation were also from the stomach. These findings are in keeping with the results of the recent studies by Wlodarska et $a l^{8}$ and Haralambieva et al. ${ }^{10} \mathrm{In}$ addition, we also found rare cases of MALT lymphoma and diffuse large B-cell lymphoma showing 4 or more extra copies of the FOXP1 gene, suggesting the presence of chromosome polysomy or FOXP1 gene amplification. ${ }^{8}$ Nonetheless, the incidences of FOXP1 translocation or gene amplification in MALT lymphoma and diffuse large B-cell lymphoma are low.

Detailed breakpoint analysis of $\mathrm{t}(3 ; 14) / F O X P 1$ $I G H$ was performed in two cases in previous studies. ${ }^{7,9}$ In one case, the FOXP1 breakpoint was 

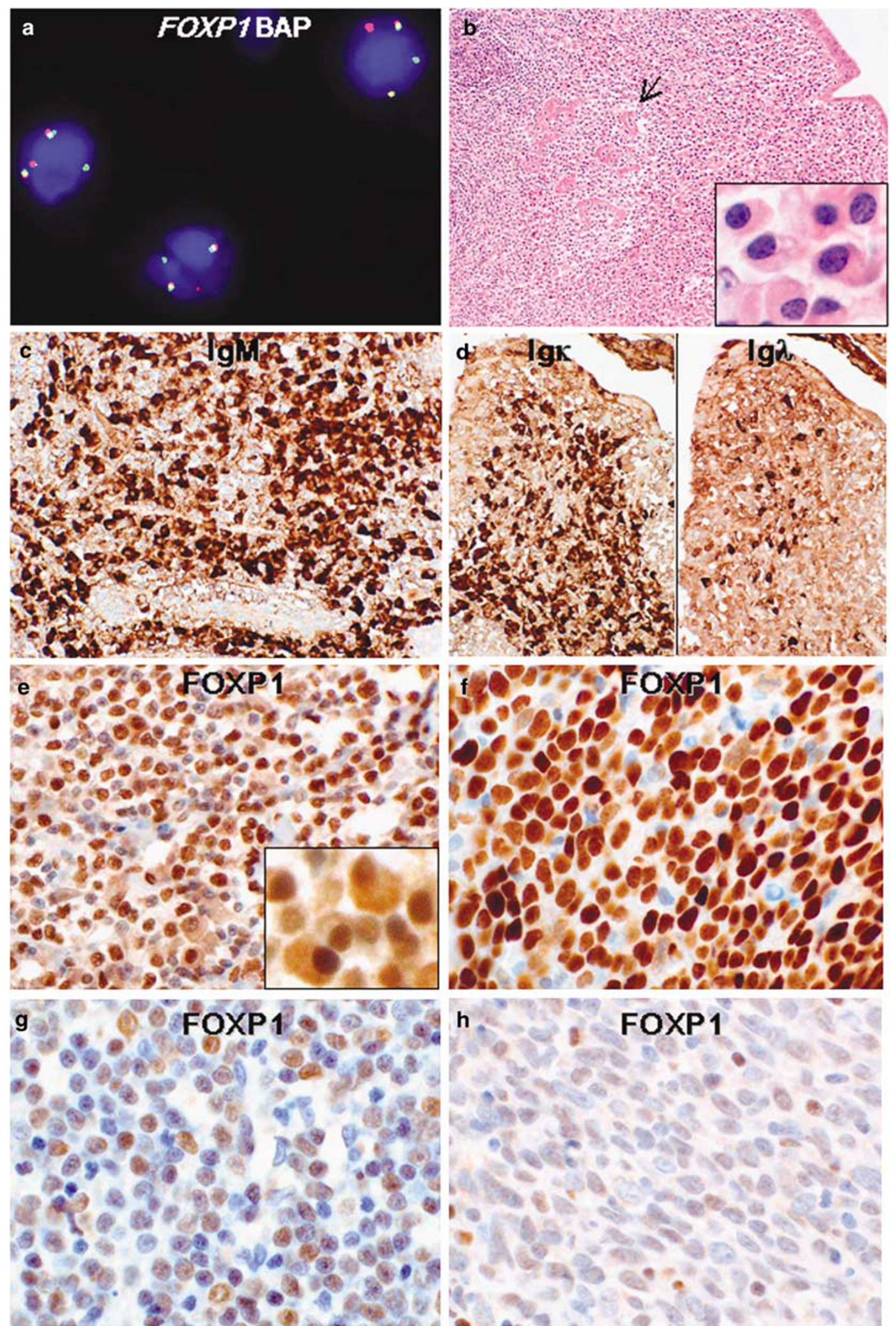

Figure 2 Examples of FOXP1 FISH and FOXP1 immunohistochemistry. FOXP1 interphase FISH with break-apart probe (BAP) set 1 shows a split signal and presence of an extra copy of the gene in a case of gastric MALT lymphoma (a). A FOXP1 translocation positive gastric MALT lymphoma shows a diffuse infiltrate of centrocyte-like cells, prominent plasma-cell differentiation and lymphoepithelial lesions (indicated by arrow) (b). The neoplastic nature of plasma cells is indicated by IgM expression (c) and Igк light chain restriction (d). FOXP1 immunohistochemistry shows strong nuclear staining in both neoplastic centrocyte-like cells and plasma cells (e). Examples of diffuse large B-cell lymphoma display strong (f), moderate (g) and weak (h) FOXP1 staining. 
$38 \mathrm{~kb}$ upstream of the first noncoding exon 1 with the remaining FOXP1 sequence joined to $I G H$ joining segment $6,{ }^{7}$ whereas in the other, the breakpoint was in intron 2 with the remaining FOXP1 sequence joined to $I G H-C \alpha 1$ but in an opposite transcriptional orientation. ${ }^{9}$ Here we show, based on analysis of 16 cases with FOXP1 translocation, that the FOXP1 breakpoint was within the $5^{\prime}$ region of the gene in most, if not all, cases. In 11 cases, the breakpoint was mapped to the region spanning intron $3-13 \mathrm{~kb}$ downstream of exon 5 . In three cases, the breakpoint was mapped to the region spanning $18 \mathrm{~kb}$ upstream of exon 1-54 kb downstream of exon 2, and the relative lengths of the exons and introns in this region suggest that the breakpoints in these cases are likely to be located downstream of exon 1. In the remaining two cases, the breakpoints were mapped to a region spanning from $60 \mathrm{~kb}$ upstream of exon 7 to exon 10, and the relative sizes of the introns and exons in this region suggest that the breakpoints are likely to be located upstream of exon 8. Significantly, these breakpoints fall within the coding sequence of full-length FOXP1, which begins in exon 6. Interestingly, Wlodarska et $a l^{8}$ reported a t(2;3)(q36;p13) involving FOXP1 and an unknown partner gene in a case of small B-cell non-Hodgkin lymphoma, in which the FOXP1 breakpoint was similarly mapped to the region spanning exon 5 to exon 7. Thus, most, if not all, of these FOXP1 breakpoints separate the downstream FOXP1 sequence from its normal promoter. Irrespective of these different breakpoints, immunohistochemistry with JC12, a monoclonal antibody to the C-terminus of FOXP1, demonstrated high-level expression of the protein in each of these translocation positive cases.

The $5^{\prime}$ end of the FOXP1 gene might also be disrupted by other means during oncogenesis. In one study FOXP1 was one of the most frequent targets of retroviral integration in myeloblastosisassociated virus type-2-induced chicken nephroblastoma. ${ }^{18}$ Significantly, all the integration events were clustered around the second coding exon (corresponding to human FOXP1 exon 7). ${ }^{18}$ Typically, the retrovirus exerts its oncogenic potential by deregulating cellular gene expression or causing alterations in the cellular gene product, consequently changing its function.

The similar disruption of the $5^{\prime}$ sequence of the FOXP1 gene by various chromosome translocations in human lymphoma and by retroviral integrations in the chicken nephroblastoma model suggests that these different events may activate the oncogenic potential of FOXP1 through a common mechanism of deregulating FOXP1 transcriptional control. As mentioned above, most, if not all, of these FOXP1 breakpoints separate the downstream FOXP1 sequence from its normal promoter. Thus FOXP1 translocation could result in the loss of normal fulllength FOXP1 mRNA expression, and expression of variant FOXP1 transcript species with alternate $5^{\prime}$ ends, most likely under the control of an alternative internal promoter. In support of this speculation, there are 14 probable alternative promoters for FOXP1 according to AceView (http:// www.humangenes.org). In addition, at least in the case of FOXP1 translocation with IGH as the translocation partner, the probability of promoter substitution is unlikely due to the opposite transcriptional orientation of the FOXP1 and IGH genes as demonstrated in detail by Fenton et al. ${ }^{9}$ More importantly, we have recently identified several FOXP1 transcript variants utilizing novel $5^{\prime}$ noncoding exons including two variants using an alternative exon $6 \mathrm{~b}$ and four variants using an alternative novel exon $7(\mathrm{a}-\mathrm{c})$ in activated B-cell-like diffuse large B-cell lymphoma. ${ }^{19}$ Furthermore, highlevel expression of smaller FOXP1 proteins was found in activated B-cell-like diffuse large B-cell lymphoma by western blotting. ${ }^{19}$ Among FOXP1 transcript variants identified, those using an alternative novel exon 7 contain the translation initiating site (two ATG) in exon 8, and thus encode N-terminally truncated proteins (lacking approximately the first 100 amino acids of the full-length FOXP1), which was consistent with the detection of smaller FOXP1 proteins by western blotting. ${ }^{19}$ Although little is known about the function of the human N-terminally truncated FOXP1 isoforms, the murine FOXP1D that lacks the N-terminal polyglutamine domain exhibits altered transregulatory properties. ${ }^{20}$ Thus, it is tempting to speculate that FOXP1 translocations, at least those with a breakpoint mapped to intron 6-7, may lead to expression of FOXP1 isoform(s) with a truncated or alternate $\mathrm{N}$-terminus.

Among the 16 cases of lymphoma with FOXP1 translocation studied, there were no obviously uniform clinical or histological features associated with the translocation. All the MALT lymphomas with FOXP1 translocation showed classic histological and immunophenotypic features of MALT lymphoma. Clinically, all four cases of FOXP1 translocationpositive gastric MALT lymphoma with long-term follow up showed durable complete remissions following gastrectomy. Of the five cases of diffuse large B-cell lymphoma with FOXP1 translocation, the histological, immunophenotypic and clinical features were also not remarkable. The markers, including CD10, Bcl6 and MUM1, commonly used for subclassification of diffuse large B-cell lymphoma into germinal center B-cell-like and nongerminal center B-cell-like subtypes were heterogeneously expressed in these cases, as described previously. ${ }^{10}$

Apart from deregulation of FOXP1 expression by chromosome translocation, overexpression of the protein was also frequently seen in MALT lymphoma and diffuse large B-cell lymphoma lacking the translocation and this was independent of FOXP1 gene copy number change. Interestingly, strong uniform FOXP1 expression was seen more 
frequently in diffuse large B-cell lymphoma (46\%) than in MALT lymphomas (25\%; Table 4), as demonstrated previously. ${ }^{3-6}$ These data, together with detection of FOXP1 translocation and gene amplification in these lymphomas suggest that FOXP1 deregulation may play an important role in their development. The findings that FOXP1 overexpression is independent of its gene translocation and copy number changes indicate the presence of other mechanisms that deregulate FOXP1 expression in lymphoma. As discussed above, we have recently identified several FOXP1 transcript variants utilizing novel $5^{\prime}$ noncoding exons and high-level expression of smaller FOXP1 protein isoforms in activated B-cell-like diffuse large B-cell lymphoma. ${ }^{19}$ Significantly, the expression of these transcript variants and the smaller protein isoforms can be induced in normal B cells following antigenic or mitogenic stimulation. ${ }^{19}$ Our localization of FOXP1 translocation breakpoints and the implications of these breakpoints for the transcriptional deregulation of FOXP1 in lymphoma provide timely and important insights to guide future investigations of the role of FOXP1 in both B-cell biology and lymphoma development.

\section{Acknowledgements}

The Du and Banham labs are supported by research grants from Leukaemia Research Fund, UK. AG is supported by a Wellcome Trust PhD studentship. CB is supported by a Senior Clinician Scientist Fellowship from The Health Foundation, The Royal College of Pathologists and The Pathological Society of Great Britain and Ireland. We thank Professor Reiner Siebert for providing FISH probes for the immunoglobulin gene loci.

\section{References}

$1 \mathrm{Hu} \mathrm{H}$, Wang B, Borde M, et al. FOXP1 is an essential transcriptional regulator of B cell development. Nat Immunol 2006;7:819-826.

2 Shaffer AL, Rosenwald A, Staudt LM. Lymphoid malignancies: the dark side of B-cell differentiation. Nat Rev Immunol 2002;2:920-932.

3 Hans CP, Weisenburger DD, Greiner TC, et al. Confirmation of the molecular classification of diffuse large B-cell lymphoma by immunohistochemistry using a tissue microarray. Blood 2004;103:275-282.

4 Banham AH, Connors JM, Brown PJ, et al. Expression of the FOXP1 transcription factor is strongly associated with inferior survival in patients with diffuse large B-cell lymphoma. Clin Cancer Res 2005;11:1065-1072.

5 Barrans SL, Fenton JA, Banham A, et al. Strong expression of FOXP1 identifies a distinct subset of diffuse large B-cell lymphoma (DLBCL) patients with poor outcome. Blood 2004;104:2933-2935.

6 Sagaert X, De Paepe P, Libbrecht L, et al. Forkhead box protein P1 expression in mucosa-associated lymphoid tissue lymphomas predicts poor prognosis and transformation to diffuse large B-cell lymphoma. J Clin Oncol 2006;24:2490-2497.

7 Streubel B, Vinatzer U, Lamprecht A, et al. $\mathrm{T}(3 ; 14)(\mathrm{p} 14.1 ; \mathrm{q} 32)$ involving $I G H$ and FOXP1 is a novel recurrent chromosomal aberration in MALT lymphoma. Leukemia 2005;19:652-658.

8 Wlodarska I, Veyt E, De Paepe P, et al. FOXP1, a gene highly expressed in a subset of diffuse large B-cell lymphoma, is recurrently targeted by genomic aberrations. Leukemia 2005;19:1299-1305.

9 Fenton JA, Schuuring E, Barrans SL, et al. $\mathrm{t}(3 ; 14)(\mathrm{p} 14 ; \mathrm{q} 32)$ results in aberrant expression of FOXP1 in a case of diffuse large B-cell lymphoma. Genes Chromosomes Cancer 2006;45:164-168.

10 Haralambieva E, Adam P, Ventura R, et al. Genetic rearrangement of FOXP1 is predominantly detected in a subset of diffuse large B-cell lymphomas with extranodal presentation. Leukemia 2006;20:1300-1303.

11 Remstein ED, Dogan A, Einerson RR, et al. The incidence and anatomic site specificity of chromosomal translocations in primary extranodal marginal zone B-cell lymphoma of mucosa-associated lymphoid tissue (MALT lymphoma) in North America. Am J Surg Pathol 2006;30:1546-1553.

12 Ye H, Liu H, Attygalle A, et al. Variable frequencies of $t(11 ; 18)(q 21 ; q 21)$ in MALT lymphomas of different sites: significant association with CagA strains of H. pylori in gastric MALT lymphoma. Blood 2003;102: 1012-1018.

13 Rohatiner A, d'Amore F, Coiffier B, et al. Report on a workshop convened to discuss the pathological and staging classifications of gastrointestinal tract lymphoma. Ann Oncol 1994;5:397-400.

14 Wotherspoon AC, Doglioni C, Diss TC, et al. Regression of primary low-grade B-cell gastric lymphoma of mucosa-associated lymphoid tissue type after eradication of Helicobacter pylori. Lancet 1993;342:575-577.

15 Du MQ, Isaccson PG. Gastric MALT lymphoma: from aetiology to treatment. Lancet Oncol 2002;3:97-104.

16 Ye $\mathrm{H}$, Gong $\mathrm{L}$, Liu $\mathrm{H}$, et al. MALT lymphoma with $\mathrm{t}(14 ; 18)(\mathrm{q} 32 ; \mathrm{q} 21) / I G H-M A L T 1$ is characterized by strong cytoplasmic MALT1 and BCL10 expression. J Pathol 2005;205:293-301.

17 Isaacson PG, Du MQ. MALT lymphoma: from morphology to molecules. Nat Rev Cancer 2004;4:644-653.

18 Pajer P, Pecenka V, Kralova J, et al. Identification of potential human oncogenes by mapping the common viral integration sites in avian nephroblastoma. Cancer Res 2006;66:78-86.

19 Brown PJ, Ashe SL, Leich E, et al. Potentially oncogenic B-cell activation induced smaller isoforms of FOXP1 are highly expressed in the activated B-celllike subtype of DLBCL. Blood 2008;111:2816-2824.

20 Wang B, Lin D, Li C et al. Multiple domains define the expression and regulatory properties of FOXP1 forkhead transcriptional repressors. J Biol Chem 2003;278: 24259-24268. 